\title{
MENINGKATKAN KEMAMPUAN KANJI MELALUI MEDIA KANJI GAME ONLINE
}

\author{
Dyah Prasetiani \\ Universitas Negeri Semarang \\ dyahprasetiani@mail.unnes.ac.id
}

\begin{abstract}
(Title: Improving Students's Skill In Reading Kanji Through Game Online Media) Japanese has several types of letters namely hiragana, katakana, kanji, and romaji. Each letter has its own uniqueness. For foreign learners, kanji is considered the most difficult. The results of interviews on the third semester students who followed the Kanji Shochukyu course showed that students often have difficulty in memorizing kanji, often forget the shape so that they are not able to write kanji correctly, and are often confused between read On and Kun. To overcome student difficulties in memorizing kanji, the author tries to use kanji media online game. The method used is experiment with experiment class and control class. The instrument used is postes. The result of the postes shows that the mean value of the experimental class is 82.5 while the control class is 70.1 .
\end{abstract}

Keywords: kanji; game online

\section{PENDAHULUAN}

Bahasa Jepang memiliki beberapa jenis huruf yakni hiragana, katakana, kanji, dan romaji. Masing-masing huruf memiliki keunikan. Bagi pembelajar asing yang mempelajari bahasa Jepang, huruf kanji dianggap yang paling sulit. Hasil studi pendahuluan terhadap mahasiswa semester III Universitas Negeri Semarang yang mengikuti mata kuliah Kanji Shochukyu, menunjukkan bahwa mahasiswaseringkali mengalami kesulitan dalam menghapal huruf kanji, seringkali lupa bentuknya sehingga tidak mampu menulis huruf kanjidengan benar, serta seringkali tertukar antara cara baca on dan kun. Hasil tes yang diperoleh mahasiswa pun masih kurang baik. Dari 70 orang mahasiswa, 39 orang (52.7\%) memperoleh nilai 70-100, dan 35 orang $(28.8 \%)$ mendapat nilai di bawah 70 . Wawancara terhadap mahasiswa yang mendapatkan nilai di bawah 70 menunjukkan hasil bahwa mereka mengalami masalah yaitu seringkali sulit menghapal, lupa bentuk huruf kanji sehingga tidak mampu menuliskannya dengan benar, seringkali tertukar antara cara baca ON dan KUN. Karena jumlah cara baca ON sangat banyak, maka ketika menemukan kanji gabungan mahasiswa sering lupa atau tidak tahu bagaimana membaca huruf tersebut.

$$
\text { Untuk mengatasi kesulitan }
$$
mahasiswa dalam menghapalkan huruf kanji tersebut, penulis mencoba untuk 
menggunakan media kanji game online. Tujuannya adalah untuk meningkatkan penguasaan kanji mahasiswa.

Media ini dipergunakan untuk latihan membaca sekaligus menghapalkan sejumlah huruf kanji dan jukugo (kanji gabungan).Dapatdilakukanolehperorangan dandilengkapidenganskor yang diperoleh.Media ini belum digunakan dalam pengajaran kanji di Program Studi Pendidikan Bahasa Jepang Universitas Negeri Semarang. Berdasarkan uraian di atas, maka penulis merumuskan masalah sebagai berikut: “Apakah kanji gameonline dapat meningkatkan kemampuan kanji mahasiswa?"

\section{TINJAUAN PUSTAKA}

\section{1) Huruf Kanji Jepang}

Huruf Kanji sebenarnya adalah tulisan Cina yang masuk ke Jepang sekitar abad ke-4 pada masa berkuasanya dinasti Kan di Cina. Pada masa itu, orang-orang Cina bermigrasi ke Jepang. Karena itu huruf tersebut disebut kanji.Yang berasal dari kata 'Kan' berarti dinasti Kan, ' $j i$ ' berarti huruf.Orang Jepang mempelajari huruf tersebut lalu membacanya sesuai pelafalan orang Cina.

Hampir semua kanji memiliki dua jenis pengucapan yaitu ON-YOMIdan KUN-YOMI. Kanji yang berdiri sendiri biasanya dibaca dengan $K U N$ sedangkan kanji yang merupakan bagian dari kata gabungan atau jukugo biasanya dibacadengan $O N$. Sebagai contoh,「石」 ‘ishi'(batu ) dibaca dengan KUN sedangkan huruf yang sama pada kata gabungan seperti「石油」 'sekiyu'(kerosene, oil, petroleum) dibaca dengan $O N$ 'seki'.

Namun tidak semua jukugo dibaca secara ON. Ada empat macam cara membaca kanji gabungan (jukugo), yaitu $\mathrm{ON}+\mathrm{ON}, \quad \mathrm{KUN}+\mathrm{KUN}, \quad \mathrm{ON}+\mathrm{KUN}$, KUN+ON. Contohnya:

心理 'shin ri' (kenyataan ) $\rightarrow$ $\mathrm{ON}+\mathrm{ON}$

真夜中 'ma yo naka' (tengah malam)

$$
\rightarrow \mathrm{KUN}+\mathrm{KUN}+\mathrm{KUN}
$$

音読 'on yomi' (cara baca Cina) $\rightarrow$ $\mathrm{ON}+\mathrm{KUN}$

足音 'ashi oto' (langkah kaki)

$\rightarrow \mathrm{KUN}+\mathrm{ON}$

Keistimewaan lain dari kanji yaitu kanjitertentu bisa memiliki lebih dari satu ON-yomi maupun KUN-yomi. Contohnya, 「形」 secara KUN dibaca 'kata' dan 'katachi' sedangkan secara ON dibaca 'kei' dan 'gyoo' (pada kata「形式」 'kei shiki' (formal), 「人形」 'nin gyoo' (boneka).

Ada juga beberapa kanji yang memiliki cara baca khusus, yang kadang- 
kadang tidak sesuai dengan ON maupun KUN. Dan ini harus dihapalkan. Contohnya:「今朝」 yang berarti "pagi ini" harus dibaca 'ke sa', bukan 'kyoo asa' atau lainnya sesuai ON dan KUN dari masing-masing kanji.

Ada kanji yang arti dan bunyinya sama namun bentuknya berbeda. Contohnya 「聞 $<」$ 'kiku' (mendengar) dan 「聴 $<」$ 'kiku' (mendengar). Keduanya berarti "mendengar". Bedanya adalah $「$ 聴 $<」$ berarti kita lebih memperhatikan yang kita dengarkan, misalnya mendengarkan music menggunakan 「聴 $く 」$ bukan $「$ 聞 $く 」$. Bisa juga cara bacanya sama tetapi artinya berbeda, misalnya 「書 $く 」$ 'kaku (menulis) dan「描く」 'kaku' (menggambar). Ada juga kanji yang dapat dibaca bermacammacam misalnya 「今日」(hari ini) dapat dibaca 'kyoo', 'konjitsu', atau 'konnichi' disesuaikan konteks kalimatnya.

\section{2) Kegunaan Media Pembelajaran}

Untuk membantu mahasiswa dalam memahami materi ajar, dosen dapat menggunakan berbagai media pembelajaran yang menarik dan bervariasi, misalnya penggunaan media gambar, permainan, teka-teki, pertanyaanpertanyaan, kartu, game, dan lain-lain.
Media pengajaran adalah segala alat pengajaran yang digunakan pengajar sebagai perantara untuk menyampaikan bahan-bahan instruksional dalam proses belajar mengajar sehingga memudahkan pencapaian tujuan pengajaran tersebut (Sumantri, 2001: 23).

Masih menurut Sumantri, media pengajaran memiliki fungsi sebagai berikut:

(1) Alat bantu untuk mewujudkan situasi belajar mengajar yang efektif

(2) Bagian integral dari keseluruhan situasi mengajar

(3) Meletakkan dasar-dasar yang konkret dari konsep yang abstrak, sehingga dapat mengurangi pemahaman yang bersifat verbalisme

(4) Membangkitkan motivasi belajar siswa

(5) Mempertinggi mutu belajar mengajar

Multimedia juga dapat digunakan sebagai media pengajaran.Berdasarkan kegunaannya multimedia pembelajaran dibagi dua jenis (Sumantri 2001: 47)

(1) Multimedia PresentasiPembelajaran. Berupa pointer-pointer materi yang disajikan (explicit knowledge). Dapatdikembangkandengan 
software presentasiseperti: Open Office Impress, Microsoft Power Pointdansebagainya.

(2) Multimedia PembelajaranMandiri. Software pembelajaran yang dapat dimanfaatkan oleh siswa secara mandiri tanpa bantuan guru. Multimedia pembelajaran mandiri harus dapat memadukan explicit knowledge (pengetahuantertulis yang ada di buku, artikel, dansebagainya) dan tacit knowledge (know how, rule of thumb, pengalaman guru). Software yang biasa digunakan antara lain Macromedia Authorware, Adobe Flash, Open Office Impress, atau Microsoft PowerPoint.

\section{3) Media Kanji Game Online}

Saat ini telah dikembangkan banyak cara sebagai media untuk belajar huruf kanji. Salah satunya dengan media game online. Saat ini terdapat banyak software kanji game yang dapat di download dari internet. Misalnya Kanji Flashcard, dan lain-lain. Media ini belum dimanfaatkan secara meluas oleh pembelajar bahasa Jepang untuk berlatih kanji. Terlebih para pembelajar level dasar. Padahal media tersebut merupakan sarana belajar mandiri yang sangat baik. Karena dapat dilakukan di mana saja, oleh siapa saja, serta ada total skor yang diperoleh. Ini bisa menjadi sebuah latihan mandiri yang efisien jika ingin meningkatkan skor atau kemampuan kanji pembelajar.

Dewasa ini mahasiswa lebih senang untuk memanfaatkan teknologi gadget yang mereka miliki. Karena itu game kanji online menjadi hal yang menarik bagi mereka untuk digunakan sebagai media belajar karena dapat diakses melalui laptop ataupun handphone mereka. Dan karena bentuknya seperti permainan (game), maka diharapkan mahasiswa akan berulangulang berlatih atau belajar huruf kanji. Karena bagaimanapun juga bila tidak diulang-ulang, maka hasilnya menjadi tidak maksimal. Jika tidak, sebanyak apapun kanji yang dipelajari perlahan akan terlupakan terlebih bila jumlah kanji baru yang dipelajarinya bertambah banyak.

\section{METODE}

Tujuan yang ingin dicapai dalam penelitian ini adalah untuk mengetahui apakah kanji game online dapat meningkatkan kemampuan kanji mahasiswa Unnes. Untuk itu penulis menggunakan metode kuantitatif.Desain penelitian yang digunakan adalah true experimental design dengan menggunakan instrumen berupa postest pada kelas eksperimen dan kelas kontol. Sebagai catatan, perlakuan hanya diberikan pada 
kelas eksperimen, sementara kelas control tidak mendapatkan perlakuan. Soal post-tes diambil dari buku Nihongo Nouryouku Shiken N3.

PopulasipadapenelitianiniadalahMa hasiswa Program Studi Pendidikan Bahasa Jepang UNNES. Sedangkan sampel pada penelitian ini adalah 27 mahasiswa semester IV Prodi Pendidikan Bahasa Jepang UNNES yang mengikuti mata kuliah Kanji Chukyu yang tergabung dalam satu rombel.

\section{HASIL DAN PEMBAHASAN}

Setelah memberikan penjelasan tentang tujuan penelitian, penulis memberikan penjelasan mengenai kanji game online yang dapat diakses oleh mahasiswa. Juga menjelaskan apa yang harus dilakukan oleh mahasiswa yang menjadi sampel penelitian. Setelah itu dilanjutkan dengan membentuk beberapa kelompok kecil lalu berlatih atau beajar kanji dengan menggunakan kanji game online di kelas. Untuk kegiatan tersebut, sebelumnya mahasiswa diinstruksikan untuk membawa laptop. Setiap anggota kelompok dianjurkan untuk ikut menjawab dan mencoba secara bergantian.

Dalam kegiatan ini, mahasiswa berhasil mengakses game-game kanji online yang menarik yang dapat digunakan untuk berlatih huruf kanji. Ada tiga website yang diakses oleh mahasiswa, yaitu:

japaneseclass.jp

nihongo-pro.com

tanoshiijapanese.com/practice

Hasil pengamatan penulis, mahasiswa terlihat senang ketika menjawab soal-soal cara membaca huruf kanji gabungan (jukugo) yang ditanyakan dalam soal game. Dan karena dalam game tersebut terdapat skor yang diperoleh pengguna, maka mahasiswa dapat segera mengukur kemampuan kanji mereka.

Selanjutnya penulis memberikan tugas kepada mahasiswa untuk menggunakan game-game kanji tersebut untuk belajar di luar jam perkuliahan.

Hasil yang diperoleh dari post-tes pada kelas eksperimen dan kontrol dapat dilihat pada tabel 1 dan 2 berikut.
Tabel 1.

Nilai Pos-tes Kelas Eksperimen

\begin{tabular}{|c|c|c|}
\hline NO & RESPONDEN & NILAI \\
\hline 1 & R1 & 84 \\
\hline 2 & R2 & 77 \\
\hline 3 & R3 & 80 \\
\hline
\end{tabular}

Tabel 2.

Nilai Pos-tes Kelas Kontrol

\begin{tabular}{|c|c|c|}
\hline NO & RESPONDEN & NILAI \\
\hline 1 & R28 & 70 \\
\hline 2 & R29 & 75 \\
\hline 3 & R30 & 55 \\
\hline
\end{tabular}




\begin{tabular}{|c|c|c|}
4 & R4 & 89 \\
\hline 5 & R5 & 91 \\
\hline 6 & R6 & 75 \\
\hline 7 & R7 & 77 \\
\hline 8 & R8 & 89 \\
\hline 9 & R9 & 82 \\
\hline 10 & R10 & 86 \\
\hline 11 & R11 & 84 \\
\hline 12 & R12 & 80 \\
\hline 13 & R13 & 86 \\
\hline 14 & R14 & 80 \\
\hline 15 & R15 & 82 \\
\hline 16 & R16 & 82 \\
\hline 17 & R17 & 89 \\
\hline 18 & R18 & 89 \\
\hline 19 & R19 & 61 \\
\hline 20 & R20 & 89 \\
\hline 21 & R21 & 68 \\
\hline 22 & R22 & 73 \\
\hline 23 & R23 & 95 \\
\hline 24 & R24 & 70 \\
\hline 25 & R25 & 98 \\
\hline 26 & R26 & 84 \\
\hline 27 & R27 & 89 \\
\hline & Rata-rata & 82,5 \\
\hline
\end{tabular}

Dari tabel di atas dapat diketahui bahwa hasil pos-tes kelas eksperimen lebih tinggi daripada kelas kontrol. Rata-rata nilai pos-tes kelas eksperimen yaitu 82,5 sedangkan nilai rata-rata post-tes kelas kontrol yaitu 70,1. Sehingga dapat dikatakan bahwa media kanji game online efektif untuk meningkatkan hasil belajar kanji mahasiswa.

\section{SIMPULAN}

Dari hasil pembahasan dapat diambil kesimpulan bahwa kanji game

\begin{tabular}{|c|c|c|}
\hline 4 & R31 & 57 \\
\hline 5 & R32 & 80 \\
\hline 6 & R33 & 52 \\
\hline 7 & R34 & 93 \\
\hline 8 & R35 & 77 \\
\hline 9 & R36 & 61 \\
\hline 10 & R37 & 57 \\
\hline 11 & R38 & 64 \\
\hline 12 & R39 & 75 \\
\hline 13 & R40 & 80 \\
\hline 14 & R41 & 59 \\
\hline 15 & R42 & 80 \\
\hline 16 & R43 & 89 \\
\hline 17 & R44 & 86 \\
\hline 18 & R45 & 64 \\
\hline 19 & R46 & 77 \\
\hline 20 & R47 & 80 \\
\hline 21 & R48 & 30 \\
\hline 22 & R49 & 80 \\
\hline 23 & R50 & 80 \\
\hline 24 & R51 & 77 \\
\hline 25 & R52 & 66 \\
\hline 26 & R53 & 45 \\
\hline \multirow[t]{2}{*}{27} & R54 & 86 \\
\hline & Rata-rata & 70,1 \\
\hline
\end{tabular}
penguasaan kanji mahasiswa. Hal ini dapat dilihat dari hasil rata-rata post test pada kelas eksperimen yang lebih tinggi daripada kelas kontrol.

Rata-rata nilai pos-tes kelas eksperimen yaitu 82,5 sedangkan nilai rata-rata post-tes kelas kontrol yaitu 70,1. Sehingga dapat dikatakan bahwa media kanji game online efektif untuk meningkatkan hasil belajar kanji mahasiswa. 


\section{DAFTAR PUSTAKA}

Chieko, Kano. Et al. 1991. Basic Kanji Book Vol. 2. Tokyo: Bojinsha Co, Ltd.

Douglas, Masako. O. 1992. Learning and teaching kanji: For students from an alphabetic background. Online. www.sabotenweb.com/bookmarks/abo ut/douglas. htmlCached - Similar.

Diunduh 16 Februari 2012

Heisig, J. W. 1985. Remembering the Kanji. Tokyo, Japan: Japan Publications Trading Co.

Sumantri, M. 2001. Strategi Belajar Mengajar. Bandung: CV Maulana

Xamuel. Kanji vs. Romaji. Online. www.xamuel.com/kanji-vs-
romaji/Cached - Similar. Diunduh 16 Februari 2012

Jurnal Medan. (2011). Peminat Bahasa Jepang Terus Meningkat. Jurnal Medan. Online:

http://medan.jurnas.com/index.php?opt ion $=$ com_content $\&$ view $=$ article $\&$ id $=61$ 812:peminatbahasa-jepang-terus$\underline{\text { meningkat } \& \text { catid }=56 \text { :akademia\& } \text { Itemi }}$ $\underline{\mathrm{d}=63}$.Diakses 15 Juli 2012

Pratama, Adithya dan Harisin, Rico. 2013. Penelitian Keefektivitasan Pembelajaran Kanji Bahasa Jepang Menggunakan Mobile Phone Berbasis Android Dan Ios.Online: journal.binus.ac.id/index.php/comtech/ article/viewFile/2660/2066. Diakses 1 April 2018 